\title{
THE IMPACT OF LEADERSHIP STYLE AND WORK ENVIRONMENT TO EMPLOYEE'S JOB SATISFACTION WITH ORGANIZATIONAL CULTURE AS MODERATING VARIABLE AT BALAI KESEHATAN PENERBANGAN JAKARTA
}

\author{
Kusnendar Sutaryo \\ Balai Kesehatan Penerbangan Jakarta \\ Email: Kusnendar_indragiri@yahoo.com \\ Dedi Purwana \\ Universitas Negeri Jakarta \\ Email: dpurwana@unj.ac.id
}

\begin{abstract}
The research aims to analyze the impact of leadership style and work environment to employee's job satisfaction with organizational culture as moderating variable at balai kesehatan penerbangan Jakarta. the research used quantitative method. The data were analyzed using structural equation modeling-partial least square. 84 public services were used as samples, but 78 samples were given questionaire back. The research revealed that: a) leadership style has impact on work environment $(0,549)$; b) leadership style influences significantly to organizational culture $(0,454)$; c) work environment doesnot have impact on organizational culture $(0,161) ; d)$ organizational culture has strong relation to job satisfaction (0,840); e) leadership style has not effect on job satisfaction $(0,038) ; f)$ work environment has not influence on job satisfaction (0,037); g) throught organizational culture, leadership style hassignificant effect on job satisfaction (0,660); and $h$ ) throught organizational culture, work environment has not siginificant effect on job satisfaction $(0,129)$.
\end{abstract}

Keywords: Leadership Style, Work Environment, Organizational Culture, and Job Satisfaction Structural Equation Modeling-Partial Least Square 


\section{PENDAHULUAN}

Kinerja organisasi dipengaruhi beragam faktor, diantaranya kepuasan kerja. Kepuasan kerja merupakan perasaan dari pegawai terhadap hasil kinerja yang telah dilakukan. Locke (2003: 92) berpendapat bahwa“keadaan emosi yang senang atau emosi positif yang berasal dari penilaian pekerjaan atau pengalaman kerja seseorang". Banyak faktor yang mempengaruhi tingkat kepuasan dalam bekerja sehingga yang tingkat kepuasan diperoleh setiap pegawai juga akan berbedabeda(Abhilasha: 2012).

Keberhasilan organisasi dalam mencapai tujuan ditentukan pula oleh kepemimpinan. Kepemimpinan adalah proses yang berdasarkan interaksi antara pemimpin dan bawahannya.Pemimpin harus dapat mengkoordinasikan sumber daya yang ada dalam organisasi. Di samping itu pemimpin harus bisa menciptakan lingkungan kerja yang kondusif. Pemimpin yang tidak baik misalnya: memiliki sifat otoriter, tidak mau mendengar saran dari bawahan, selalu menciptakan konflik. Sedangkan contoh pemimpin yang baik misalnya: mau mendengarkan saran dari bawahan, memiliki integritas yang tinggi, memiliki sifat keteladanan yang baik.

Faktor lain terkait kepuasan kerja adalah lingkungan kerja. Menurut Sedarmayanti (2009) lingkungan kerja adalah segala sesuatu yang ada disekitar pekerja dan dapat mempengaruhi dirinya dalam melaksanakan tugas yang dibebankan kepadanya (Rizwan et al.; 2012).Timpe (1999) menyatakan bahwa lingkungan kerja fisik berpengaruh pada moral. Lingkungan fisik adalah tempat di mana seorang karyawan menyelesaikan pekerjaan di kantornya.Lingkungan kerja yang buruk menimbulkan ketidaknyamanan pegawai dalam melaksanakan pekerjaan. Sebaliknya lingkungan kerja yang baik akan memberikan rasa tenang dan nyaman pegawai dalam melaksanakan pekerjaan.

Budaya sebagai sesuatu yang telah melekat dalam diri seseorang yang berasal dari lingkungan. Budaya tidak akan mudah untuk dihilangkan dalam waktu yang relatif singkat. Menurut Schein (2013) budaya didefinisikan sebagai campuran dari seperangkat nilai, kepercayaan, komunikasi, dan tingkah laku yang menjadi pedoman bagi manusia yang dipengaruhi oleh perilaku, norma, dan kepercayaan yang menjadi 
komunikasi yang kuat diantara pekerja. Budaya akan membawa efek bagi pegawai yang bersangkutan dan organisasi.

Budaya organisasi yang buruk dapat dilihat dari tingkat kedatangan yang sering terlambat di kantor, waktu istirahat yang terlalu lama, kebiasaan menerima uang tips. Sebaliknya, budaya organisasi yang baik misalnya: kehadiran dan pulang kerja yang tepat waktu, tingginya keterlibatan yang dilakukan di dalam organisasi, bersedia datang ke kantor walaupun tidak menerima uang lembur. Penelitian yang dilakukan oleh Sami dan Sabri (2011) dan Ahmed (2015) menyimpulkan bahwa budaya organisasi mempunyai hubungan yang positif dan signifikan terhadap kepuasan kerja.

Peneliti sangat tertarik untuk meneliti keterkaitan budaya organisasi, lingkungan kerja, dan gaya kepemimpinan dalam kaitannya dengan kepuasan kerja pegawai pada Balai Kesehatan Penerbangan. Rumusan masalah dalam penelitian ini adalah: 1) Apakah gaya kepemimpinanberpengaruh terhadap lingkungan kerja?; 2) Apakah gaya kepemimpinanberpengaruh terhadap budaya organisasi?; 3) Apakah lingkungan kerjapengaruhberpengaruh terhadap budaya organisasi?; 4) Apakah budaya organisasi berpengaruh terhadap kepuasan kerja?; 5) Apakah gaya kepemimpinanberpengaruh terhadap kepuasan kerja?; 6) Apakah lingkungan kerja berpengaruh terhadap kepuasan kerja?; 7) Apakah budaya organisasi berfungsi sebagai variabel pemediasi dalam hubungan gaya kepemimpinan terhadap kepuasan kerja?; dan 8) Apakah budaya organisasi berfungsi sebagai variabel pemediasi dalam hubungan lingkungan kerja terhadap kepuasan kerja?

\section{KAJIAN TEORITIS}

\section{Kepemimpinan}

Dalam organisasi diperlukan seorang pemimpin yang bisa mengkoordinasikan semua komponen yang ada di dalamnya. Menurut Northouse (2014) kepemimpinan adalah proses seseorang untuk mempengaruhi sekelompok orang untuk mencapai tujuan. Pada masa sekarang pemimpin tidak mengandalkan kekuasaan mereka untuk membujuk orang lain untuk melakukan kehendaknya, tetapi 
mereka saling berinteraksi dengan bawahan untuk meningkatkan bawahan namun tetap menjaga jarak dengan bawahan.

Organisasi agar dapat tercapai tujuan harus mempunyai visi dan misi. Untuk pencapainya harus mengunakan suatu perencanaan, pengorganisasian, pengendalian, pengawasan dan juga strategi yang tepat. Oleh karenanya dibutuhkan seorang pemimpin yang bisa mengkoordinasikan semua yang terlibat dalam suatu organisasi. Menurut Hemphill dan Coons (2012) kepemimpinan adalah perilaku yang mengarahkan sekelompok orang untuk memenuhi dan mencapaitujuan serta misi organisasi. Sementara Kent (2005) kepemimpinan adalah proses yang berdasarkan interaksi antara pemimpin dan bawahannya menjadi efektif dari perubahan dan pengembangan serta mempengaruhi perilaku dan motivasi pengikutnya. Selanjutnya menurut Kouzes and Posner (2007) melalui studi kasus dan pertanyaan menyatakan bahwa praktek kepemimpinan sebagai “proses yang menantang” untuk mengispirasi dalam visi, yaitu: enable others to act (mengajak bertindak kepada orang lain), model the way (cara model), encourage the heart (dorongan hati).

\section{Lingkungan Kerja}

Lingkungan kerja merupakan sumber kepuasan kerja, keluhan mengenai lingkungan kerja adalah simbol atau perwujudan dari frustasi yang dalam, karena itu perlu mendapatkan perhatian dari manajemen. Oleh karena itu aspek lingkungan kerja sangat erat hubungannya dengan kinerja para pegawai.Menurut Sedarmayanti (2009) lingkungan kerja adalah segala sesuatu yang ada disekitar pekerja dan dapat mempengaruhi dirinya dalam melaksanakan tugas yang dibebankan kepadanya. Sedangkan menurut Rachmawati (2003) lingkungan adalah faktor-faktor yang berada di luar dan di dalam jangkauan organisasi yang dapat menimbulkan suatu peluang atau ancaman.

Timpe (1999) menyatakan bahwa lingkungan kerja berpengaruh pada moral yaitu lingkungan fisik. Lingkungan fisik adalah tempat di mana seorang karyawan menyelesaikan pekerjaan di kantornya.Kondisi tempat kerja yang berhubungan dekat dengan lingkungan kerja, seperti: penerangan, suara, keadaan udara, dan sebagainya. Lingkungan kerja pada dasarnya terbagi menjadi: (a)lingkungan fisik: ventilasi/penerangan, layout, dan peralatan, (b) the psyco-social: para karyawan akan 
dapat dengan mudah berinteraksi dengan membawa efek yang positif (Simamora; 2004). Lebih jauh, Brill (1992)berpendapat bahwafaktor-faktor yang dapat mempengaruhi terbentuknya suatu kondisi lingkungan kerja dikaitkan dengan kemampuan pegawai, diantaranya adalah: (1) penerangan/cahaya, (2) suhu, kelembaban, (4) sirkulasi udara, (5) kebisingan, (6) hubungan di antara rekan, (7) bau-bauan, (8) fasilitas, (9) hubungan dengan atasan, (10) sarana, (11) keamanan.

\section{Budaya Organisasi}

Organisasi yang mempunyai pegawai dengan latar belakang budaya yang berbeda tentu akan membawa norma-norma yang beranekaragam.Setiap organisasi mempunyai budaya tersendiri berbeda dibandingkan organisasi lain. Menurut Kotter and Heskett (1992)budaya organisasi adalah sesuatu yang dikonsepkan dan dibagikan atas kepercayaan dan nilai dari organisasi yang membantu untuk membentuk perilaku karyawan. Sedangkan menurut Robbin (2002) budaya organisasi adalah suatu persepsi bersama yang dianut oleh anggota-anggota yang berada didalam organisasi merupakan pembeda dengan organisasi lain.

Indikator dalam budaya organisasi menurut Schein (2002) adalah: (1) norma yaitu standar perilaku yang ada dalam kelompok yang dapat diterima kelompok tersebut; (2) nilai dominan, adanya dukungan dan harapan dari anggota organisasi untuk berbagi dengan nilai yang dominan; (3) psikologi yaitu kepercayaan organisasi sebagai pedoman kebijakan sebagaimana pegawai dan pelanggan harus dijaga; (4) iklim yaitu atmosphere secara keseluruhan yang disampaikan dalam organisasi dengan layout secara fisik, dan cara pegawai berinteraksi dengan pelanggan.

Luthans (2011) berargumen terdapat 6 karakteristik dalam mengidentifikasi budaya organisasi : (1) Observed behaviorregulation yaitu: apabila para partisan organisasi saling berkaitan satu sama yang lain itu berinteraksi antar anggota organisasi maupun interaksi antar anggota dengan orang-orang yang berhubungan dengan organisasi, maka mereka akan mengunakan bahasa, terminologi dan ritualitas yang sama dengan rasa hormat dan cara bertindak; (2) Norm, yaitu standar-standar perilaku yang ada, mencakup pedoman tentang apa saja yang tidak boleh dilakukan; (3) Dominant value yaitu: ada sejumlah nilai-nilai utama yang organisasi anjurkan dan harapkan kepada anggota organisasi untuk menyumbangkannya, misalnya: 
absensi yang rendah, dan efisiensi yang tinggi; (4) Phylosophy, yaitu ada sejumlah kebijakan yang menyatakan keyakinan organisasi tentang bagaimana para pegawai dan masyarakat sebagai pelanggan diperlakukan; (5) Rules, yaitu ada sejumlah pedoman pasti yang berhubungan yaitu sejumlah pedoman pasti yang berhubungan dengan kemajuan atau cara berhubungan dalam berorganisasi. Para pegawai baru harus mempelajari ikatan atau value yang ada sehingga mereka dapat diterima sepenuhnya sebagai anggota baru dalam organisasi; (6) Organizational climate yaitu: ada sesuatu perasaan yang dibawa oleh individu, cara anggota memperlakukan dirinya menghadapi masyarakat dan pihak dari luar.

\section{Kepuasan Kerja}

Karyawan yang bekerja bukan hanya mencari uang, tetapi juga mencari kepuasan. Itu berarti bahwa kepuasan merupakan kebutuhan yang didambakan oleh setiap pegawai. Menurut Slochum (2007)kepuasan kerja menjadi penting, tidak saja bagi pegawai, tetapi juga bagi organisasi. Urgensi itu terkait dengan fakta-fakta empirik bahwa kepuasan menunjukkan hasil pengalaman kerja dan tingkat kekecewaan tinggi yang membantu menunjukkan masalah organsasi yang memerlukan perhatian. Selain itu, kekecewaan kerja berkaitan erat dengan absen, pergantian pegawai dan masalah kesehatan fisik dan mental. Lebih dari itu, ketika pegawai tidak puas dengan pekerjaanya, keterlibatan kerja menjadi berkurang, komitmen pada organisasi rendah, suasana sangat negatif, dan serangkaian akibat negatif akan muncul. Pegawai yang tidak puas bisa terlibat dalam kemerosotan psikologis, kemerosotan fisik (tidak masuk tanpa alasan, pulang lebih awal, istirahat yang terlalu lama, ataupun keterlambatan), ataupun tindakan agresi berlebihan dan pembalasan terhadap kesan terjadi.

Di sisi yang lain Newstorm (2007)menyatakan para pegawai yang puas bisa membuat tindakan pelayanan konsumen di luar panggilan tugasnya, membuat laporan yang baik, dan aktif dalam semua bidang pekerjaan. Hal ini mengisyaratkan betapa kepuasan kerja sangat penting dan vital bagi kehidupan pegawai dan organisasi, sehingga perlu dipelihara keberadaannya dan ditingkatkan dari waktu ke waktu. Menurut Locke (2003) kepuasan kerja yang meliputi reaksi atau kognitif, afektif, dan evaluatif dan menyatakan bahwa kepuasan kerja adalah"keadaan emosi 
yang senang atau emosi positif yang berasal dari penilaian pekerjaan atau pengalaman kerja seseorang”. Kepuasan kerja adalah hasil dari persepsi pegawai mengenai seberapa baik pekerjaan mereka memberikan hal yang dinilai penting.

Faktor-faktor yang mempengaruhi kepuasan kerja menurut Vijayakumar et al. (2008: 29-34)adalah: 1) Kerja nyata: lingkungan kerja, situasi kerja, posisi, jaringan komunikasi; 2) Ringkasan kerja: yaitu yang berhubungan dengan pengawasan, rekan kerja, fungsi demokrasi, perilaku dan moral; 3) Psychosocial:yaitu yang berhubungan dengan status sosial, promosi, perilaku; 4) aspek ekonomi:yaitu gaji dan upah; dan 5) pertumbuhan komunitas: yaitu sumbangan terhadap pertumbuhan ekonomi nasional, dan kualitas kehidupan.Sedangkan menurut Robbins et al. (2002: 93) faktor-faktor yang mempengaruhi kepuasan kerja adalah: 1) lingkungan kerja; 2) gaji; 3) promosi; dan 4) pengawasan.

\section{Hipotesis Penelitian}

1) Diduga terdapat pengaruh gaya kepemimpinan terhadap lingkungan kerja.

2) Diduga terdapat pengaruh gaya kepemimpinan terhadap budaya organisasi.

3) Diduga terdapat pengaruh lingkungan kerja terhadap budaya organisasi.

4) Diduga terdapat pengaruh budaya organisasi terhadap kepuasan kerja.

5) Diduga terdapat gaya kepemimpinan terhadap kepuasan kerja.

6) Diduga terdapat pengaruh lingkungan kerja terhadap kepuasan kerja.

7) Diduga terdapat pengaruh budaya organisasi berfungsi sebagai variabel pemediasi dalam hubungan gaya kepemimpinanterhadap kepuasan kerja.

8) Diduga terdapat pengaruh budaya organisasi berfungsi sebagai variabel pemediasi dalam hubungan lingkungan kerjaterhadap kepuasan kerja.

\section{METODE PENELITIAN}

Penelitian ini dilakukan pada kantor Balai Kesehatan Penerbangan Jakarta. Penelitian ini mengunakan pendekatan kuantitatif, metode survey dan tehnik korelasional. Subjek penelitian ini adalah semua Aparatur SipilNegara yang bekerja pada Balai Kesehatan Penerbangan kecuali Kepala Kantor, Kepala Seksi Program dan Kepala Sub Bagian Tata Usaha sebanyal 87 orang. Sampel penelitian berjumlah 84 orang dengan teknik sensus. 
Data primer dikumpulkan melalui penyebaran kuisioner yang didesign dalam bentuk skala Likert dan skala peringkat rating scale. Analisis data yang digunakan dalam penelitian ini meliputi: analisis statistik deskriptif, uji asumsi klasik (persyaratan analisis), dan analisis statistik parametik (interferensial). Metode analisis data yang digunakan dalam penelitian ini adalah Partial Least Square (PLS)Structural Aquation Modeling (SEM).Penelitian ini lebih bersifat memprediksi dan menjelaskan variabel laten daripada menguji suatu teori, dan jumlah sampel penelitian ini yang relatif sedikit, serta untuk mengantisipasi jika data terdistribusi tidak normal (Hair et al., 2014:4).

Pada model struktural terdapat 4 (empat) inner variabel dalam penelitian ini, yang terdiri dari: Gaya Kepemimpinan $\left(\mathrm{X}_{1}\right)$, Lingkungan kerja $\left(\mathrm{X}_{2}\right)$ sebagai variabel bebas, Budaya Organisasi (Y), dan Kepuasan Kerja (Z). Pada model pengukuran outer model, pembentukan variabel latendalam penelitian ini merefleksikan yang berarti keempat variabel laten mempengaruhi indikator. Dari semua variabel terdapat 15 (lima belas) dimensi, dan 39 (tigapuluh sembilan) indikator, yang meliputi: variabel gaya kepemimpinan memiliki 4 (empat) dimensi dan 15 (lima belas) indikator, lingkungan kerja memilik 2 (dua) dimensi dan 7 (tujuh) indikator, budaya organisasi memiliki 2 (dua) indikator dan 12 (dua belas) indikator, kepuasan kerja memiliki 5 (lima) dimensi dan 5 (lima) indikator.Evaluasi PLS-SEM untuk evaluasi outer model mengunakan model reflektive, yang terdiri dari: (1) indikator reliability, dengan nilai 0,5-0,7; (2) discriminant validity, dengan syarat AVE, > 0,6; (3) internal consistency, dengan syarat composite reliability $\leq 0,6$ (4) Convergent Validity AVE > 0,5 (Hair et al., 2014:6)

\section{HASIL PENELITIAN DAN PEMBAHASAN}

\section{A. Model Pengukuran}

Pada analisis model pengukuran ditinjau validitas model pengukuran dan reliabilitas model pengukuran dengan $>0,50$. Dan untuk kriteria reliabilitas dengan nilai $\mathrm{AVE} \geq 0,50$ dan $\mathrm{CR} \geq 0,70$. Tabel 1 menunjukkan hasil uji reliabilitas composit (composit reliability measure). 
Tabel 1. Hasil Uji Composite Reliability (CR)

\begin{tabular}{ccccccc}
\hline No & Variabel & Dimensi & Validitas & AVE & CR & Reliabilitas \\
\hline 1 & Gaya & 1 & Valid & 0,438 & 0,756 & Reliable \\
& Kepemimpinan & 2 & Valid & 0,481 & 0,787 & \\
& & 3 & Valid & 0,660 & 0,795 & \\
2 & Lingkungan Kerja & 1 & Valid & 0,717 & 0,835 & \multirow{2}{*}{ Reliable } \\
& & 2 & Valid & 0,427 & 0,748 & \\
3 & Budaya Organisasi & 1 & Valid & 0,708 & 0,829 & \multirow{2}{*}{ Reliable } \\
& & 2 & Valid & 0,393 & 0,717 & \\
4 & Kepuasan Kerja & 1 & Valid & - & - & \multirow{2}{*}{ Reliable } \\
& & 2 & Valid & - & - & \\
& & 3 & Valid & - & - & \\
\hline
\end{tabular}

Berdasarkan hasil perhitungan di atas, maka variabel gaya kepemimpinan yang terdiri dari dimensi 1 dengan nilai AVE $(0,438)$, dimensi 2 dengan nilai AVE $(0,481)$, dimensi 3 dengan nilai $\operatorname{AVE}(0,660)$, dan dimensi 4 dengan nilai AVE $(0,717)$ dinyatakan reliable. Variabel lingkungan kerja yang terdiri dari dimensi 1 dengan nilai AVE $(0,427)$, dimensi 2 dengan nilai AVE $(0,708)$, dinyatakan reliable. Selanjutnya variabel budaya organisasi yang terdiri dari dimensi 1 dengan nilai AVE $(0,343)$, dimensi 2 dengan nilai AVE $(0,395)$, dinyatakan reliable. Dan pada variabel kepuasan kerja yang terdiri: dimensi 1, dimensi 2, dimensi 3 tidak memiliki nilai AVE artinya semua indikator pada tiap-tiap dimensi dapat langsung mempengaruhi variabel laten (kepuasan kerja), tanpa harus melalui demensi terlebih dahulu.

Hasil uji komfirmasi analisis (CFA) untuk setiap variabel dapat dilihat pada tabel di bawah ini;

Tabel 2. Hasil Uji Validitas (CFA)

\begin{tabular}{cccccc}
\hline No & Variabel & Validitas & $\begin{array}{c}\text { AVE } \\
\text { (Indikator) }\end{array}$ & CR & Reliabilitas \\
\hline 1 & $\begin{array}{c}\text { Gaya } \\
\text { Kepemimpinan }\end{array}$ & Valid & 0,326 & 0,858 & Reliable \\
2 & $\begin{array}{c}\text { Lingkungan Kerja } \\
3\end{array}$ & Valid & 0,289 & 0,725 & Reliable \\
4 & Budaya Organisasi & Valid & 0,283 & 0,820 & Reliable \\
& Kepuasan Kerja & Valid & 0,285 & 0,676 & Reliable
\end{tabular}


Berdasarkan tabel 2di atas terlihat bahwa seluruh nilai standardized loading factornilai $\mathrm{CR}$ seluruh variabel nilai $\geq 0,6$. Namun, keseluruhan nilai tersebut signifikan secara statistik. Oleh karena itu dapat ditarik kesimpulan bahwa seluruh indikator dari setiap variabel adalah valid dan reliable.

\section{B. Analisis Model Struktural}

Analisis Model Struktural berhubungan terhadap koefesien-koefisien atau parameter-parameter yang menunjukkan pengaruh hubungan antara variabel laten terhadap variabel laten lainnya. Berdasarkan hasil dari perhitungan kuesioner terhadap responden yang telah terkumpulkan dan diolah dengan mengunakan SEMPLS, maka diperoleh model struktural sebagai berikut:

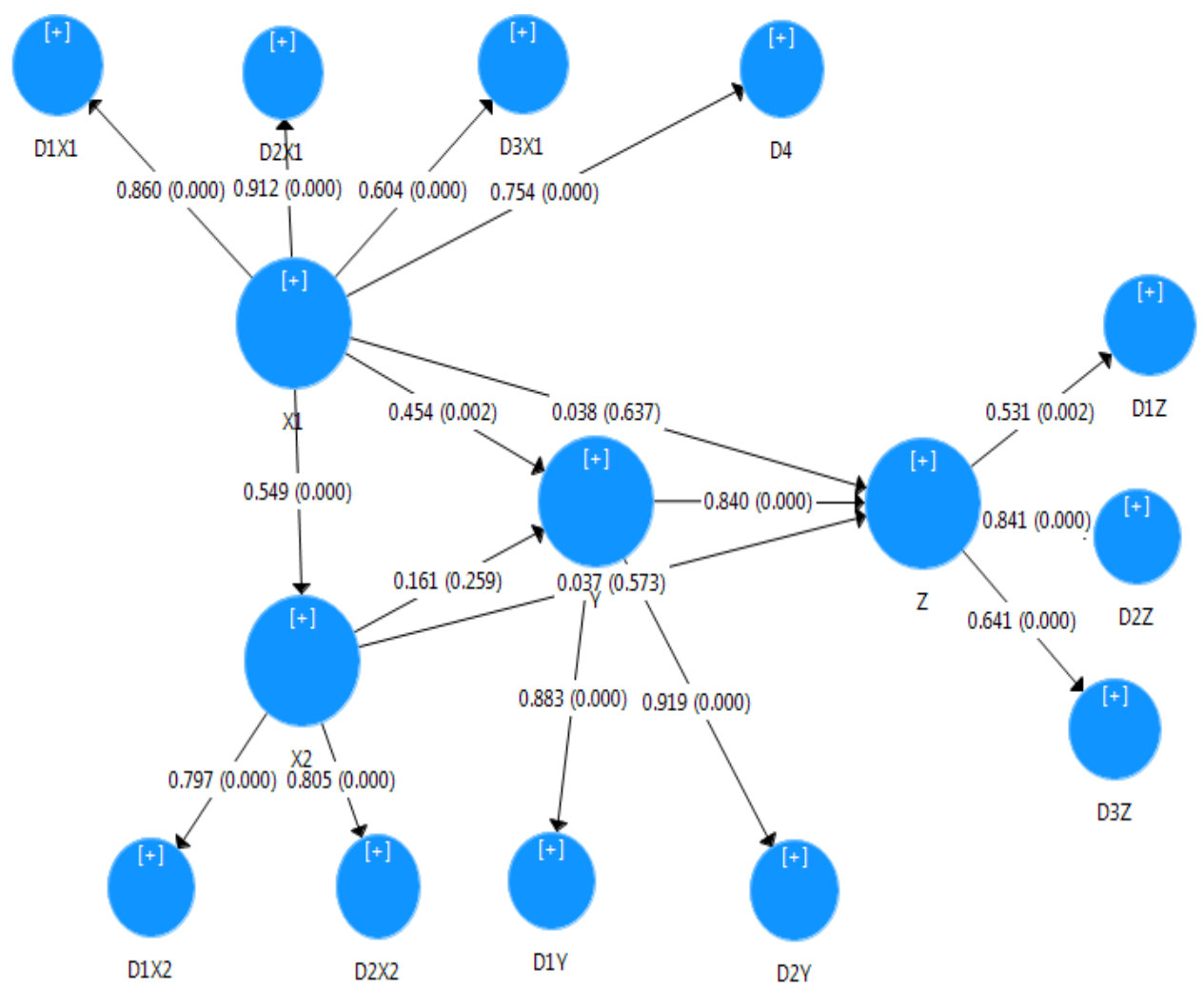

Gambar 1. Path Coefisien

Model struktural tersebut digunakan untuk menguji hipotesis penelitian. Adapun rekapitulasi hasil uji hipotesis berdasarkan nilai P-value adalah sebagai berikut: 


\section{Tabel 3.Uji Hipotesis}

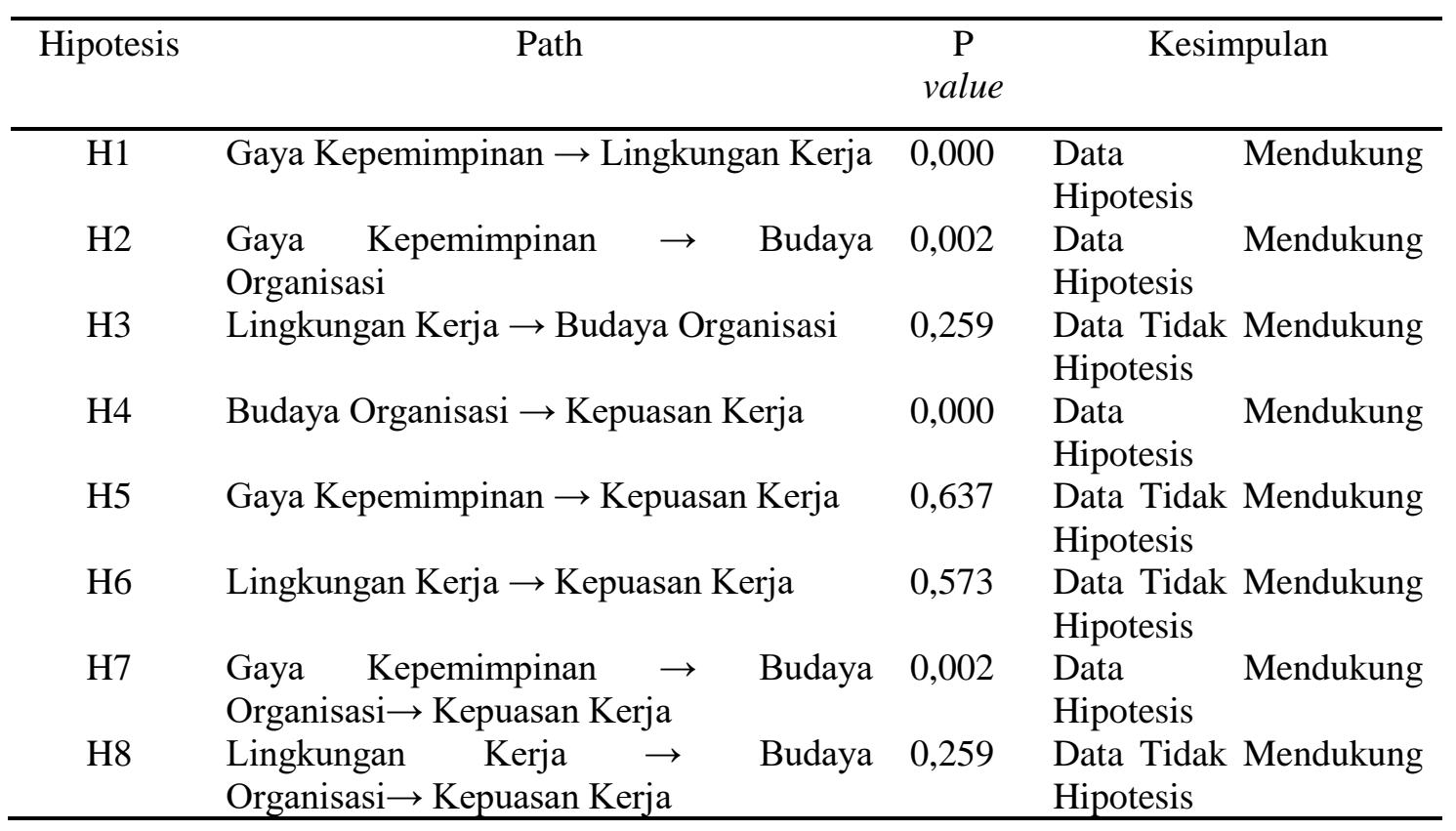

\section{Interprestasi Hipotesis Penelitian}

Pada analisis model pengukuran dalam penelitian ini menunjukkan bahwa seluruh variabel telah memenuhi kriteria validitas dan reliabilitas.Berikut ini dijelaskan interprestasi hipotesis penelitian.

\section{Gaya Kepemimpinan Terhadap Lingkungan Kerja}

Hasil pengujian H1 menunjukkan bahwa gaya kepemimpinan memiliki hubungan yang positif terhadap lingkungan kerja. Jika gaya kepemimpinan baik, maka kantor Balai Kesehatan Penerbangan akan dapat membentuk lingkungan kerja yang baik. Sebaliknya, jika gaya kepemimpinan tidak baik, maka kantor Balai Kesehatan Penerbangan akan terbentuk lingkungan kerja yang kurang baik.

Pada periode tahun 2015 sampai dengan 2016 di kantor Balai Kesehatan Penerbangan telah mengalami 3 (tiga) kali pergantian pemimpin. Pimpinan memiliki latar belakang budaya, pendidikan yang berbeda-beda.Ada pimpinan yang memiliki latar belakang Penerbang, dan Medis.Menurut Dubrin et al. (2007) dalam jurnal yang berjudul Impact of Leadership Styles on Followers' Job Satisfaction: A Four Frame Model Approach, kepemimpinan adalah suatu tindakan untuk memimpin 
sekumpulan orang-orang untuk mencapai tujuan dari organisasi. Kepemimpinan akan membantu pegawai untuk menjawab tujuan organisasi secara umum ketika pegawai dipengaruhi oleh pimpinannya.

Salah satu bentuk dari gaya kepemimpinan adalah bagaimana seorang pemimpin dalam mempengaruhi bawahan agar bersedia bekerja secara rajin, dan memberi motivasi kerja bawahannya.Hemphill dan Coons (2012) menyatakan bahwa kepemimpinan adalah perilaku yang mengarahkan sekelompok orang untuk memenuhi dan mencapai tujuan serta misi organisasi. Hal ini didukung oleh penelitian yang dilakukan oleh Doucet et al. (2009) yang membuktikan bahwa kepemimpinan transformasional mempunyai hubungan yang negatif terhadap motivasi inspirasional $(\beta=1 / 4-0.22 ; p<0.001)$, namun tetap memiliki pengaruh.

\section{Hasil Uji Gaya Kepemimpinan Terhadap Budaya Organisasi}

Hasil pengujian $\mathrm{H} 2$ menunjukkan bahwa gaya kepemimpinan memiliki hubungan yang positif terhadap buadaya organisasi. Jika gaya kepemimpinan baik, maka kantor Balai Kesehatan Penerbangan akan dapat membentuk budaya organisasi yang baik. Sebaliknya, jika gaya kepemimpinan tidak baik, maka kantor Balai Kesehatan Penerbangan akan terbentuk budaya organisasi yang kurang baik.

Dalam pergantian pemimpin ada beberapa kebijakan yang berbeda antara satu pimpinan dengan pimpinan yang lainnya. Seorang pemimpin mempunyai gaya tersendiri dalam memimpin organisasi. Ada beberapa perbedaan yang dirasakan oleh pegawai dari setiap pimpinan. Budaya yang diterapkan oleh pimpinan membawa pengaruh kepada budaya organisasi. Perilaku pimpinan akan menjadi keteladanan bagi para bawahannya. Karakter yang dibawa dimiliki oleh pimpinan mungkin akan diterapkan oleh bawahan. Budaya organisasi akan terbentuk dari kebiasan-kebiasan dari pegawai.

Budaya didefinisikan sebagai campuran dari seperangkat nilai, kepercayaan komunikasi, dan tingkah laku yang menjadi pedoman bagi manusia yang dipengaruhi oleh perilaku, norma, dan kepercayaan yang menjadi komunikasi yang kuat diantara pekerja (Schein; 2013).Kent (2005) berpendapat bahwa kepemimpinan adalah proses yang berdasarkan interaksi antara pemimpin dan bawahannya menjadi efektif dari 
perubahan dan pengembangan serta mempengaruhi perilaku dan motivasi pengikutnya. Jadi kepemimpinan dapat membentuk suatu nilai yang dikonsepkan, dan menjadi suatu nilai yang dapat di terapkan dalam suatu organisasi, sehingga dapat menjadi pedoman perilaku bagi karyawan. Hal ini didukung oleh penelitian yang dilakukan oleh Nurwati et al. (2012) kepemimpinan berpengaruh terhadap budaya organisasi, dimana $\mathrm{P}$ value $0,000<\mathrm{P} 0,005$.

\section{Hasil Uji Lingkungan Kerja Terhadap Budaya Organisasi}

Hasil pengujian H3 menunjukkan bahwa lingkungan kerja memiliki hubungan yang positif terhadap budaya organisasi. Jika lingkungan kerja baik, maka kantor Balai Kesehatan Penerbangan akan dapat membentuk budaya organisasi yang baik. Sebaliknya, jika lingkungan kerja tidak baik, maka kantor Balai Kesehatan Penerbangan akan terbentuk budaya organisasi yang kurang baik.

Pada periode tahun 2015 sampai dengan 2016 di kantor Balai Kesehatan Penerbangan telah mengadakan peralatan laboratorium, peralatan pemeriksaan fisik, komputer, alat timbang badan, data base, penambahan tenaga honorer, dan ANS, yang berguna untuk menunjang kinerja. Terkadang kurang tersedianya pegawai dan peralatan membuat rasa iri terhadap unit kerja yang ada. Dengan demikian akan timbul prasangka buruk di antara rekan kerja. Budaya organisasi akan menjadi kurang baik. Sebaliknya, apabila peralatan kerja, tenaga kerja tersedia secara cukup, maka prasangka terhadap rekan kerja akan baik. Lingkungan kerja yang kurang baik dikhawatirkan akan menjadi kebiasaan di organisasi. Kebiasaan-kebiasaan yang tumbuh di dalam organisasi akan dapat menjadi budaya.

Berdasarkan hasil pembahsan hipotesis di atas, maka dapat disimpulkan bahwa lingkungan kerja di kantor Balai Kesehatan Penerbangan mempunyai pengaruh terhadap budaya organisasi. Hal ini sesuai dengan yang dinyatakan oleh Rachmawati (2003) lingkungan adalah faktor-faktor yang berada di luar dan di dalam jangkauan organisasi yang dapat menimbulkan suatu peluang atau ancaman. Sementara menurut Kotter and Heskett (1992)budaya organisasi adalah sesuatu yang dikonsepkan dan dibagikan atas kepercayaan dan nilai dari organisasi yang membantu untuk membentuk perilaku karyawan. Hubungan antara rekan kerja, 
antara atasan dengan bawahan merupakan salah satu bentuk lingkungan kerja non fisik. Lingkungan kerja ini merupakan salah satu bentuk perilaku karyawan. Lingkungan kerja non fisik yang baik dapat ditingkatkan untuk dijadikan budaya pada organisasi. Hal ini didukung oleh penelitian yang dilakukan oleh Chandrasekar (2012) yang membuktikan bahwa Lingkungan kerja mempunyai peranan yang penting dalam memotivasi karyawan untuk meningkatkan kinerja mereka.

\section{Hasil Uji Budaya Organisasi Terhadap Kepuasan Kerja}

Hasil pengujian H4 menunjukkan bahwa budaya organisasi memiliki hubungan yang positif terhadap kepuasan kerja. Jika budaya organisasi baik, maka kantor Balai Kesehatan Penerbangan akan dapat meningkatkan kepuasan kerja pegawainya. Sebaliknya, jika budaya organisasi tidak baik, maka kantor Balai Kesehatan Penerbangan akan menurunkan tingkat kepuasan kerjanya.

Selama kurun waktu dari tahun 2015 sampai dengan 2016 di kantor Balai Kesehatan Penerbangan telah meningkat tingkat kepuasan kerja. Hal ini bisa dilihat dari faktor kedatangan yang lebih awal, tingkat absensi yang menurun, meningkatnya partisipasi pegawai dalam kegiatan yang dilaksanakan oleh kantor Balai Kesehatan Penerbangan. Bersedia untuk datang ke tempat kerja, walaupun pada hari libur dan tidak diberi uang lembur. Sebaliknya ketidakpuasan kerja pegawai bisa dilihat dari kedatangan yang sering terlambat, tingkat absensi yang tinggi, tidak bersedia untuk berpartisipasi dalam kegiatan yang dilaksanakan oleh kantor Balai Kesehatan Penerbangan, waktu istirahat yang terlalu lama.

Menurut Locke (2003) kepuasan kerja yang meliputi reaksi atau kognitif, afektif, dan evaluatif dan menyatakan bahwa kepuasan kerja adalah "keadaan emosi yang senang atau emosi positif yang berasal dari penilaian pekerjaan atau pengalaman kerja seseorang”. Perilaku yang positif dari karyawan, norma-norma yang baik dalam organisasi, komunikasi yang harmonis di antara karyawan akan menjadi budaya organisasi yang baik. Karyawan akan merasa nyaman, tenang, dan perasaan yang senang dengan keadaan tersebut. Hal ini akan mendorong karyawan akan meningkatkan kinerjanya. Penelitian yang dilakukan oleh Sabri (2011) dan 
Ahmed (2015) membuktikan bahwa budaya organisasi berhubungan dengan kepuasan kerja karyawan.

\section{Hasil Uji Gaya Kepemimpinan Terhadap Kepuasan Kerja}

Hasil pengujian H5 menunjukkan bahwa gaya kepemimpinan memiliki hubungan yang positif terhdap kepuasan kerja. Jika gaya kepemimpinan yang sesuai dengan keadaan pegawai yang memiliki beragam karakter, memungkinkan akan banyak keanekaragaman tingkat kepuasan kerja. Gaya kepemimpinan yang dapat diterima oleh semua elemen akan mendapatkan respond yang positif dari pegawainya. Sebaliknya, jika gaya kepemimpinan tidak sesuai dengan keinginan pegawai dan organisasi, maka akan terjadi sikap acuh bahkan penolakan terhadap kebijakan dari pimpinan. Sebagai akibatnya akan menurunkan tingkat kepuasan kerjanya.

Dalam pergantian pemimpin ada beberapa kebijakan yang berbeda antara satu pimpinan dengan pimpinan yang lainnya. Seorang pemimpin mempunyai gaya tersendiri dalam memimpin organisasi. Ada beberapa perbedaan yang dirasakan oleh pegawai dari setiap pimpinan. Gaya kepemimpinan yang diterapkan oleh pimpinan membawa pengaruh kepada kepuasan kerja. Ada beberapa macam pimpinan antara lain: pimpinan yang hanya mau pegawai dituntut untuk melakukan pekerjaan secara terus-menerus, mau mendorong agar bawahan menjadi pandai dalam melakasanakan pekerjaan, mengikutsertakan dalam pendidikan dan pelatihan demi tercapainya tujuan dari organisasi.

Berdasarkan hasil pembahsan hipotesis di atas, maka dapat disimpulkan bahwa gaya kepemimpinan di kantor Balai Kesehatan Penerbangan mempunyai pengaruh terhadap kepuasan kerja. Hal ini sesuai dengan yang diungkapkan oleh Winston dan Patterson (2006) pemimpin adalah seseorang yang memilih, melatih dan memandu satu orang atau lebih dan karena orang-orang yang secara antusias berkoordinasi serta usaha mereka untuk mencapai tujuan organisasi. Hal ini didukung oleh penelitian yang dilakukan oleh Yun et al. (2007). Adapun pembuktian dari hipotesisnya adalah kepemimpinan trasnformasional dan Kepemimpinan empoweiring mempunyai pengaruh terhadap kepuasan kerja $(\beta=.21, \alpha<.05 ; \beta=$ 
$.23, \alpha<.05)$. Kepemimpinan adversifmempunyai pengaruh yang negatif terhadap kepuasan kerja $(\beta=-.17, \alpha<.10)$,

\section{Hasil Uji Lingkungan Kerja Terhadap Kepuasan Kerja}

Hasil pengujian H6 menunjukkan bahwa lingkungan kerja memiliki hubungan yang positif terhadap kepuasan kerja. Kantor Balai Kesehatan Penerbangan telah mengadakan peralatan laboratorium, peralatan pemeriksaan fisik, komputer, alat timbang badan, data base, penambahan tenaga honorer, dan PNS, yang berguna untuk menunjang kinerja. Dengan kinerja yang baik, maka diharapkan akan dapat memberikan kepuasan bagi pegawai, organisasi dan juga penguna jasa dari kantor Balai Kesehatan Penerbangan.

Sebagai salah satu bentuk dari tingkat kepuasan kerja pegawai bisa dilihat dari faktor kedatangan yang lebih awal, tingkat absensi yang menurun, meningkatnya partisipasi pegawai dalam kegiatan yang dilaksanakan oleh kantor Balai Kesehatan Penerbangan. Bersedia untuk datang ke tempat kerja, walaupun pada hari libur dan tidak diberi uang lembur. Sebaliknya ketidakpuasan kerja pegawai bisa dilihat dari kedatangan yang sering terlambat, tingkat absensi yang tinggi, tidak bersedia untuk berpartisipasi dalam kegiatan yang dilaksanakan oleh kantor Balai Kesehatan Penerbangan, waktu istirahat yang terlalu lama.

Berdasarkan hasil pembahsan hipotesis di atas, maka dapat disimpulkan bahwa lingkungan kerja di kantor Balai Kesehatan Penerbangan mempunyai pengaruh terhadap budaya organisasi.Hal ini sesuai dengan pendapat Sedarmayanti (2009) lingkungan kerja adalah segala sesuatu yang ada disekitar pekerja dan dapat mempengaruhi dirinya dalam melaksanakan tugas yang dibebankan kepadanya. Menurut Slochum (2007)kepuasan kerja menjadi penting, tidak saja bagi pegawai, tetapi juga bagi organisasi. Urgensi itu terkait dengan fakta-fakta empirik bahwa kepuasan menunjukkan hasil pengalaman kerja dan tingkat kekecewaan tinggi yang membantu menunjukkan masalah organsasi yang memerlukan perhatian. Lingkungan kerja menjadi salah satu sumber pendukung kinerja pegawai. Ketersediaan peralatan, hubungan di antara rekan kerja dan atasan akan memberikan pengaruh kenyaman dan ketenangan pegawai dalam melaksanakan tugasnya. Kinerja pegawai akan menjadi 
meningkat karena ketersedian peralatan kerja, dan hubungan kerja yang baik. Dengan meningkatnya kinerja pegawai, diharapkan tingkat kehadiran di kantor menjadi baik, tingkat absensi rendah, keterlibatan dalam kegiatan di organisasi menjadi meningkat. Hal tersebut merupakan salah satu bentuk dari tingkat kepuasan dari pegawai. Dukungan dari teori ini dilakukan oleh penelitian yang dilakukan oleh Oyekunle et al. (2012) yang membuktikan hipotesisnya bahwa salah satu faktor dari lingkungan kerja adalah peraturan. Peraturan yang jelas memainkan peranan yang penting bagi komitmen karyawan (Mean=3.784, SD=0.966), untuk pekerjaan mereka. Hasil penemuan yang menyatakan bahwa ada hubungan yang kuat dan positif antara variabel kepuasan kerja dan komitmen pekerjaan. Ini menyatakan bahwa survey kualitatif pada pelayanan umum di Nigeria adalah karyawan lebih komit terhadap pekerjaan mereka ketika karyawan lebih puas dengan pekerjaan mereka. Sedangkan penelitian yang dilakukan oleh Muhammad Rizwan et al. (2012) membuktikan lingkungan kerja, $(\beta=0.233)$ and $(\mathrm{p}<0.000)$ yang berarti lingkungan kerja berkontribusi $30 \%$ terhadap kepuasan kerja.

\section{Hasil Uji Gaya Kepemimpinan Melalui Budaya Organisasi, Gaya \\ Kepemimpinan Terhadap Kepuasan Kerja}

Dalam penelitian ini terdapat intervening variabel yaitu budaya organisasi. Suatu variabel disebut intervening variable jika variabel tersebut ikut mempengaruhi hubungan antara variabel independen dan variabel dependen.

Tabel 4. Hubungan Struktural $\mathrm{X} 1 \rightarrow \mathrm{Y} \rightarrow \mathrm{Z}$

\begin{tabular}{cccc}
\hline Hipotesis & Hubungan Variabel & Sobel Test & Keterangan \\
\hline $\mathrm{H} 7$ & $\mathrm{X} 1 \rightarrow \mathrm{Y} \rightarrow \mathrm{Z}$ & 0,660 & Diterima \\
\hline
\end{tabular}

Pengaruh tidak langsung X1 ke Z melalui Y dihitung dengan cara mengalikan jalur $\mathrm{X} 1 \rightarrow \mathrm{Y}$ (a) dengan jalur $\mathrm{Y} \rightarrow \mathrm{Z}$ (b) atau ab. Berdasarkan perhitungan, diperoleh nilaierror koefisienab $=0,660$. Selanjutnya apabila dibandingkan antara pengaruh langsung antara gaya kepemimpinan terhadap kepuasan kerja yang nilai koefisien estimasi sebesar 0,038 maka akan didapat hasil bahwa nilai tersebut akan 
lebih besar dari pada nilai pengaruh tidak langsung yang didapatkan dari perkalian antara nilai koefisien estimasi $\mathrm{H} 2$ dan $\mathrm{H} 4(0,454$ x $0,840=0,3816)$. Dengan demikian karena koefisien estimasi untuk pengaruh langsung lebih besar dari tidak langsung $(0,038<0,3816)$, maka dapat diartikan bahwa gaya kepemimpinan lebih lemah berhubungan secara langsung terhadap kepuasan kerja tanpa melalui mediasi variabel budaya organisasi.Hal ini sejalan dengan penelitian yang dilakukan oleh Samson (2016) bahwa gaya kepemimpinan, dan kepuasan kerja secara bebas dan gabungan antara kinerja yang telah diuji dengan mengunakan analisis regresi berganda

\section{Hasil Uji Melalui Budaya Organisasi, Lingkungan Kerja Berpengaruh Terhadap Kepuasan Kerja}

Uji Sobel dilakukan dengan cara menguji kekuatan pengaruh tidak langsung variabel independen X2 ke variabel dependen $(\mathrm{Z})$ melalui intervening variable $(\mathrm{Y})$.

Tabel 5. Hubungan Struktural $X 2 \rightarrow Y \rightarrow Z$

\begin{tabular}{cccc}
\hline Hipotesis & Hubungan Variabel & Sobel Test & Keterangan \\
\hline $\mathbf{H 7}$ & $\mathrm{X} 2 \rightarrow \mathrm{Y} \rightarrow \mathrm{Z}$ & 0,073 & Ditolak \\
\hline
\end{tabular}

Pengaruh tidak langsung X2 ke Z melalui Y dihitung dengan cara mengalikan jalur $\mathrm{X} 2 \rightarrow \mathrm{Y}$ (a) dengan jalr $\mathrm{Y} \rightarrow \mathrm{Z}$ (b) atau ab. Berdasarkan perhitungan diperoleh nilai error koefisien $a b=0,0731$. Selanjutnya apabila dibandingkan antara pengaruh langsung antara lingkungan kerja terhadap kepuasan kerja yang nilai koefisien estimasi sebesar 0,037 maka akan didapat hasil bahwa nilai tersebut akan lebih besar dari pada nilai pengaruh tidak langsung yang didapatkan dari perkalian antara nilai koefisien estimasi $\mathrm{H} 3$ dan $\mathrm{H} 4(0,454 \times 0,840=0,3816)$. Dengan demikian karena error koefisien untuk pengaruh langsung lebih besar dari tidak langsung $(0,037<0,0731)$ maka dapat diartikan bahwa lingkungan kerja tidak berpengaruh secara langsung terhadap kepuasan kerja tanpa melalui mediasi variabel budaya organisasi. 


\section{KESIMPULAN DAN SARAN}

\section{Kesimpulan}

Penelitian ini menyimpulkan bahwa:

1. Gaya kepemimpinan mempunyai pengaruh posif dan signifikan terhadap lingkungan kerja dengan nilai koefisien estimasi sebesar 0,549.

2. Gaya kepemimpinan mempunyai pengaruh positif dan signifikan terhdapa budaya organisasi dengan nilai koefisien estimasi sebesar 0,454.

3. Lingkungan kerja tidak mempunyai pengaruh yang positif dan tidak signifikan terhadap budaya organisasi dengan nilai koefisien estimasi sebesar 0,161.

4. Budaya organisasi mempunyai pengaruh yang positif dan signifikan terhadap kepuasan kerja dengan nilai nilai koefisien estimasi sebesar 0,840.

5. Gaya kepemimpinan tidak berpengaruh dan signifikan terhadap variabel kepuasan kerja dengan nilai koefisien estimasi sebesar 0,038.

6. Lingkungan kerja tidak mempunyai pengaruh yang positif dan tidak signifikan terhadap kepuasan kerja dengan nilai sebesar 0,037 .

7. Gaya kepemimpinan melalui budaya organisasi mempunyai pengaruh positif dan signifikan terhadap kepuasan kerja dengan nilai koefisien estimasi sebesar 0,667.

8. Lingkungan kerja melalui budaya organisasi tidak mempunyai pengaruh positif dan signifikan terhadap kepuasan kerja karena $\mathrm{P}$ value 0,129 lebih kecil dari $\mathrm{P}$ value 0,005 . Sedangkan nilai koefisien estimasi pada hubungan ini adalah 0,500.

\section{Saran}

Berdasarkan hasil penelitian, Balai Kesehatan Penerbangandisarankan melakukan upaya-upaya:

1. Gaya kepemimpinan yang diterapkan oleh seorang pimpinan akan dapat menciptakan situasi kerja bagi pegawai. Oleh karena itu perlu adanya gaya kepemimpinan yang dapat meningkatkan lingkungan kerja yang lebih harmonis, kondusif, sehingga pegawai akan dapat merasakan lingkungan kerja yang nyaman dan tenang. 
2. Seorang pimpinan dapat menerapkan gaya kepemimpinan yang sesuai dengan tujuan organisasi, dan tidak bertentangan dengan budaya organisasi, sehingga pegawai dapat merasakan kebiasaan yang dijalani tidak harus berubah secara drastis untuk mengikuti gaya dari seorang pimpinan. Suasana tersebut akan membuat pegawai tidak merasa asing dengan kebiasan yang mereka laksanakan. Budaya yang diterapkan oleh pegawai tidak akan berubah secara signifikan yang diakibatkan oleh gaya kepemimpinan.

3. Meningkatkan lingkungan kerja, seperti peningkatkan komunikasi antar pegawai, pegawai dengan atasan, adanya pertemuan yang dapat mempererat silahturahi, terpenuhi akan kebutuhan pegawai, sehingga karyawan akan merasa nyaman dalam melaksanakan tugas. Kondisi tersebut bisa dijadikan suatu kebiasaan, sehingga akan dapat melekat pada diri setiap pegawai. Hal ini akan mengurangi rasa kurang percaya, rasa curiga di antara rekan kerja. Dengan meningkat lingkungan kerja yang baik, diharapkan akan semakin baik budaya organisasi.

4. Perlu ditingkatkan rasa tolong menolong di antara rekan kerja, peningkatan kreativitas pegawai, peningkatkan kerja sama dalam melaksanakan tugas yang dapat diterapkan dalam budaya kerja. Karena budaya organisasi terbukti mempunyai pengaruh terhadap kepuasan kerja, maka budaya organisasi perlu ditingkatkan lebih baik lagi, sehingga akan dapat meningkatkan kepuasan kerja.

5. Walaupun gaya kepemimpinan tidak berpengaruh terhadap kepuasan kerja, namun sebaiknya gaya kepemimpinan yang diterapkan oleh pimpinan dapat diterima oleh semua pegawai. Sehingga pegawai akan tetap dapat melaksanakan tugas-tugas yang diberikan oleh pimpinan tanpa adanya perbedaan prosedur dengan yang diperintahkan oleh pimpinan.

6. Walaupun lingkungan kerja tidak mempunyai pengaruh terhadap kepuasan kerja,namun alangkah baiknya lingkungan kerja yang ada harus bisa nyaman, tenang, aman. Apabila pegawai dalam melaksanakan tugas secara nyaman, tenang, dan aman, maka pegawai akan melaksanakan kerja secara optimal.

7. Dari gaya kepemimpinan terbukti mempunyai pengaruh terhadap kepuasan kerja pegawai melalui budaya kerja. Perlu adanya penerapan gaya kepemimpinan yang 
sesuai dengan keadaan organisasi untuk dapat meningkatkan budaya organisasi, sehingga dapat meningkatkan kepuasaan kerja.

8. Walaupun lingkungan kerja tidak mempunyai pengaruh terhadap kepuasan kerja melalui budaya organisasi, namun perlu adanya peningkatkan lingkungan kerja yang baik, yang akan dapat membentuk budaya organisasi agar menjadi lebih baik, sehingga dapat meningkatkan kepuasan kerja.

\section{DAFTAR PUSTAKA}

Chandrasekar. K. (2011), Workplace Environment and Its Impact on Organisational Performance in Public Sector Organisations. International Journal of Enterprise Computing and Business Systems (Online) Vol. 1 Issue 1 January. DuBrin, A. J. (2007). Leadership research: Findings, practice, and skills (5th ed.). Boston, MA: Houghton Mifflin Company.

Ishfaq, Ahmed. (2010). Effects of Motivational Factors on Employees Job Satisfaction a Case Study of University of the Punjab, Pakistan, Vol. 5, No3.

Kent, Thomas, (2005). “Leading And Managing: It Takes Two Tango”, Journal of Management Decision, International Journal of Business and management.43, (7/8):1010-1017.

Kotter, J. P. \& Heskett, J. L., (1992). Corporate Culture and Performance. New York: Free Press,

Kouzes. M. James and Posner.Z. Barry., (2007). Leadership Challenge. Fourth Edition. Jhon Wiley and Son, Inc

Locke, E. A. Toward., (2003). A Theory of Task Motivation and Incentives. Organizational behavior and human performance. New York: McGraw- Hill.

Luqman, Oyekunle, Oyewobi Bolaji Suleiman \& Abubakar Muhammad-Jamil. (2012). Job Satisfaction and Job Commitment: A Study of Quantity Surveyors in Nigerian Public Service. Department of Quantity Surveying, Federal University of Technology, Minna, Niger State, Nigeria. Vol. 7, No. 5.

Luthans, Fred., (2011). Organizational Behavior. New York: McGraw-Hill Companies Inches. 
Manz, C. C., \& Sims, H. P., Jr. (2001). The new superleadership: Leading others to lead themselves

Rizwan, Muhammad, Waqas Mehmood Khan (Corresponding Author), Hafiz Muhammad Aqeel Tariq, Abdul Ghaffar, Malik Zubair Anjum, Ehsan Ullah Bajwa. (2012). Empirical study of Employee job Satisfaction, e-ISSN: 2278487X, p-ISSN:2319-7668, pp 29-35.

Newstorm, Jhon. W., (2007). Organizational Behavior. Boston: McGrawhill.

Northouse, P. G., (2007). Leadership: Theory and practice (4th ed.). Thousand Oaks, CA: Sage.

Pierce, J. L., \& Newstorm, J. W., (2008). Leaders \& the leadership process: readings, self-assessment \& applications (5th ed.). New York, NY: McGrawHill/Irwin.

Robbin. P. Stephen., (2002). The Principles of Organization Behavior. Edition 5th. Jakarta: Erlangga.

Saba, Irum. (2011). Measuring the Job Satisfaction Level of the Academic Staff in Bahawalpur Colleges. International Journal of Academic Research in Business and Social Sciences. Vol. 1, No. 1.

Schein, E., (2013). Organizational Culture and Leadership. San Francisco: JosseyBass.

Sedarmayanti., (2009). Manajemen Sumber Daya Manusia, Reformasi Birokrasi dan Menejemen Pegawai Negeri Sipil. Cetakan Ketiga. Bandung: Refika Aditama.

Seokhwa Yun, Jonathan Cox, Henry P. Sims, Jr., Sabrina Salam. (2007). Leadership and Teamwork: The Effects of Leadership and Job Satisfaction on Team Citizenship Vol. 2 Iss. 3, pp. 171-193 (C) School of Global Leadership \& Entrepreneurship, Regent University. ISSN 1554-3145.

Simamora, Henry., (2004). Manajemen Sumber Daya Manusia. Yogyakarta: Penerbitan: STIE YKPN.

Singh, Abhilasha. (2012). Job Satisfaction Among the Expatriates in the UAE American University in the Emirates Dubai, UAE Volume -2, No.-5.

Slochum J. W. and Hellriegel.D., (2007). Fundamental of organissational behavior. 
Southwestern: Thomson.

Timpe, A. D., (1999). Seri Manajemen Sumber Daya Manusia "Kinerja", Cetakan Keempat, Jakarta: PT. Elex Media Komputindo. 